\title{
Diuretic Effect of Cymbopogon jwarancusa after Single and Multiple Doses in Rats
}

\author{
Sarah Jameel Khan, Syeda Afroz, Rafeeq Alam Khan* \\ Department of Pharmacology, Faculty of Pharmacy and Pharmaceutical Sciences, University of Karachi, Karachi, Pakistan \\ Email: ${ }^{*}$ rkhan1959@gmail.com
}

How to cite this paper: Khan, S.J., Afroz, S. and Khan, R.A. (2018) Diuretic Effect of Cymbopogon jwarancusa after Single and Multiple Doses in Rats. Pharmacology \& Pharmacy, 9, 250-256. https://doi.org/10.4236/pp.2018.97019

Received: May 12, 2018

Accepted: July 17, 2018

Published: July 20, 2018

Copyright (c) 2018 by authors and Scientific Research Publishing Inc. This work is licensed under the Creative Commons Attribution International License (CC BY 4.0).

http://creativecommons.org/licenses/by/4.0/

\section{(c) (i) Open Access}

\begin{abstract}
Diuretics are efficaciously used in management of various clinical emergencies like hypertension, heart failure, cirrhosis, hypercalciuria, hematuria and nephrotic syndrome. Cymbopogon jwarancusa is an aromatic perennial grass used in both traditional and Unani system of medicine to eradicate diseases like colds, seasonal fever, asthma, tuberculosis, rheumatic pain, back pain, toothache and nervous disorders. $C$. jwarancusa essential oils are used in perfumery, soap, detergents, medicines and pharmaceutical industry. Monoterpenes and sesquiterpenes constitute the highest composition in essential oil of C. jwarancusa. The present was designed to compare the diuretic activity of $C$. jwarancusa after single and multi-doses. Furosemide $(20 \mathrm{mg} / \mathrm{kg})$ was used as reference drug and $10 \%$ DMSO was used as vehicle. Diuretic activity was noticed by measuring urine volume and calculating diuretic and Lipchitz values. Maximum diuretic response was observed at $500 \mathrm{mg} / \mathrm{kg}$ of extract after both single and multi-dose administration. On basis of results it may be concluded that $C$. jwarancusa may be used as diuretic agent.
\end{abstract}

\section{Keywords}

Cymbopogon jwarancusa, Diuretic, Dimethyl Sulfoxide, Lipchitz Value, Furosemide

\section{Introduction}

Maintenance of homeostasis is very important for a normal healthy life, since existence of life becomes difficult if any change disturbs this balance. Diuretics preserve this balance by maintain blood volume as well as concentration of excess ions in the body. These properties enable diuretics to treat various pathologies e.g. hypertension, congestive heart failure, hypercalciuria, edema, nephritic syndrome, cirrhosis and renal dysfunctions [1] [2]. Hypertension is a 
worldwide problem and its management gains priority each day. Survey of 2000 in adult population showed that around 972 million people had hypertension. This number is predicted to increase up of 1.56 billion by 2025 [3].

Diuretics mainly alters the excretion of electrolytes and water by acting on renal tubules. Various classes of diuretics include carbonic anhydrase inhibitors, thiazide, loop, potassium sparing and osmotic diuretics [4]. However loop diuretics are most effective as causes excretion of $20 \%-25 \%$ of sodium and water while thiazide diuretics are moderate in action causing excretion of $5 \%-8 \%$ sodium whereas potassium sparing diuretics are least effective since excrete only $2 \%$ - $3 \%$ of sodium.

Most common undesired effects of diuretics are hypomagnesaemia, hyponatrimea, hyperglycemia, hypercholesterolemia, hyperuricemia, hypokalemia while less common side effects are weakness, impotence and fatigue [5].

In modern era herbal remedies are preferred over traditional medicines in eradicating numerous diseases, but are slow in action however thought to produce less side effects. $C$. jwarancusa is an aromatic perennial grass (Rusha grass, khavi grass) belonging to family Poaceaea, used in both traditional and Unani system of medicine for treatment of various ailment e.g. vomiting, fever, inflammatory condition, blood impurities and skin problems [6]. Monoterpenes and sesquiterpenes constitute the highest composition in essential oil extracted from $C$. jwarancusa. The Specie name of plant is a combination of two Sanskrit words jwar and khusha means fever breaker [7]. In literature $C$. jwarancusa have been used as anti-pyretic [8], anti-fungal [9], antibacterial [10], anti-oxidant and cytotoxic agent [11]. However there is lack of documented evidence regarding diuretic activity of $C$. jwarancusa. Thus current study is designed to explore the diuretic potential of $C$. jwarancusa leaves extract at different does after single and multiple doses.

\section{Materials and Methods}

\subsection{Collection of Plant and Extraction}

Aerial parts of $C$. jwarancusa were collected from University of Karachi and identified by herbarium, Department of Botany. A voucher specimen No. 93325 was then deposited in the herbarium. The parts of the plant were washed to remove impurities, dried, chopped and soaked in ethanol for 20 days. The filtered extract was then evaporated by rotary evaporator, freeze dried and kept in refrigerator for further examination.

\subsection{Selection of Animals and Handling}

The study was conducted on albino Wister rats of both sex (140 - 200 gm.) obtained from the animals house of ICCBS, University of Karachi. All the animals were kept at the animal house of Department of Pharmacology, University of Karachi, in plastic cages with 12 -h light/dark cycle at $22^{\circ} \mathrm{C} \pm 2{ }^{\circ} \mathrm{C}$ and $50 \%-60 \%$ humidity for a period of one week before the start of experiment. Animals were 
fed standard diet and water regularly and were handled according to the guidelines of National Institute of Health for care and use of animals [12]. All doses of C. jwarancusa 150, 300 and $500 \mathrm{mg} / \mathrm{kg}$ and standard drug, furosemide $20 \mathrm{mg} / \mathrm{kg}$ were prepared in $10 \%$ DMSO and administered by oral intubation tube.

\subsection{Design of Study}

Diuretic activity was examined using Lipschitz method. Animals were randomly divided into five groups designated as negative control, positive control and three treated groups each comprising of 6 animals. Animals were deprived of food and water for 15 hours then given normal saline by mouth in a dose of $25 \mathrm{ml} / \mathrm{kg}$ before administration of vehicle, standard drug and herbal extract, to enforce water balance and salt load. After administration of standard and treated drugs all animals were separately placed in especially designed metabolic cages for collection of urine. Animals were given food and water ad libitum during the total period of experiment.

\subsubsection{Single Dose Response}

Single dose response of the vehicle, standard drug and herbal extract at three doses was examined in animal groups pre-treated with normal saline. Negative control group received only $10 \%$ DMSO. Positive control group was given furosemide $(20 \mathrm{mg} / \mathrm{kg})$ and treated groups received 150,300 and $500 \mathrm{mg} / \mathrm{kg}$ of $C$. jwarancusa extract. Drugs and vehicle were given in the equivalent volume to all animals once a day. Urine volume was measured continuously every hour up to five hours and then after 24 hours.

\subsubsection{Multiple-Dose Response}

Protocol for multiple-dose was same as that for single dose, except that test and standard drugs were administered daily in the same dose for five days. Urine volume was measured daily for 5 days at an interval of 24 hours. However readings on 5th day demonstrated cumulative result of urine volume from day 1 to 5 .

\subsubsection{Estimation of Diuretic Parameters}

Diuretic index and Lipschitz value were determined by following formulas [13].

$$
\begin{aligned}
\text { Diuretic index } & =U V t / U V c \\
\text { Lipschitz value } & =U V r / U V c
\end{aligned}
$$

where, $U V t$ is mean urine volume of test group. $U V r$ is mean urine volume of reference group. $U V c$ is mean urine volume of control group.

\subsection{Statistics}

All statistical calculation were performed by SPSS version 20 and values are expressed as mean \pm S.E.M. For comparison studies one way ANOVA was used, followed by post hoc (Dunnett's test). Values of $p<0.05$ were considered as significant diuretic and values of $\mathrm{p}<0.001$ as highly significant diuretic. All graph- 
ical data interpreted by Microsoft excel.

\section{Results}

\section{Diuretic Activity}

\section{1) Effect on urine volume}

Table 1 and Figure 1 show urinary output after single and multiple-dose of test and standard drugs. Result shows that groups received single and multiple-doses of furosemide have highly significant increase in urine output i.e. $15.51 \pm 0.48 \mathrm{ml}$ and $37.56 \pm 3.36 \mathrm{ml}$ as compared to control group i.e. $6.40 \pm 0.94$ $\mathrm{ml}$ and $22.31 \pm 1.55$ respectively. However, animals received $500 \mathrm{mg} / \mathrm{kg}$ of $C$. jwarancusa extract displayed significant increase in urine output as compared to control both after single and multiple-doses i.e. $9.51 \pm 1.3 \mathrm{ml}$ and $34 \pm 3.14 \mathrm{ml}$. Animals received $300 \mathrm{mg} / \mathrm{kg}$ of extract exhibited significant urinary output only at 3rd and 4th day on as compared to control group.

\section{2) Effect on diuretic index and Lipschitz value}

Table 2 shows comparative effect of diuretic index and Lipschitz values after single and multiple-doses of test and standard drugs. Diuretic index values after single dose of furosemide and 150, 300 and $500 \mathrm{mg} / \mathrm{kg}$ of $C$. jwarancusa extract were $2.42,1,1.36$ and 1.48 respectively whereas in animals received multiple-doses of furosemide and 150, 300 and $500 \mathrm{mg} / \mathrm{kg}$ of $C$. jwarancusa extract showed diuretic values of $1.68,1.22,1.35$ and 1.52 respectively.

Lipschitz values of $C$. jwarancusa extract at 150,300 and $500 \mathrm{mg} / \mathrm{kg}$ were $41 \%$, $56 \%$ and $61 \%$ after single dose and $72 \%, 80 \%$ and $90 \%$ after multiple doses as compared to furosemide.

\section{Discussion}

Plants play very beneficial role in human life; not only provides nutritional benefits but also has medicinal value. In recent time's medicinal plant has been targeted to be used as drug for eradicating variety of diseases. According to WHO

Table 1. Effect of $C$. jwarancusa, furosemide and DMSO on urine volume in rats.

\begin{tabular}{|c|c|c|c|c|c|c|c|c|c|c|}
\hline \multirow{2}{*}{ Treatment } & \multicolumn{10}{|c|}{ Urine volume (ml) } \\
\hline & $1 \mathrm{hr}$ & $2 \mathrm{hr}$ & $3 \mathrm{hr}$ & $4 \mathrm{hr}$ & $5 \mathrm{hr}$ & $24 \mathrm{hr}$ & 2nd day & 3rd day & 4th day & 5 th day \\
\hline $10 \%$ DMSO & $0.56 \pm 0.15$ & $1.41 \pm 0.27$ & $2.20 \pm 0.37$ & $2.85 \pm 0.41$ & $3.45 \pm 0.37$ & $6.40 \pm 0.94$ & $9.08 \pm 1.33$ & $11.68 \pm 1.24$ & $16.30 \pm 1.63$ & $22.31 \pm 1.55$ \\
\hline $\begin{array}{l}\text { Furosemide } \\
20 \mathrm{mg} / \mathrm{kg}\end{array}$ & $\begin{array}{l}4.25 \pm \\
0.28^{\star *}\end{array}$ & $\begin{array}{l}5.96 \pm \\
0.16^{\star *}\end{array}$ & $\begin{array}{l}6.28 \pm \\
0.24^{\star *}\end{array}$ & $\begin{array}{l}7.61 \pm \\
0.23^{\star *}\end{array}$ & $\begin{array}{l}8.25 \pm \\
0.12^{\star *}\end{array}$ & $\begin{array}{c}15.51 \pm \\
0.48^{\star *}\end{array}$ & $\begin{array}{c}26.18 \pm \\
2.94^{\star *}\end{array}$ & $\begin{array}{c}29.93 \pm \\
3.28^{\star *}\end{array}$ & $\begin{array}{l}32.71 \pm \\
3.16^{\star *}\end{array}$ & $\begin{array}{c}37.56 \pm \\
3.36^{* *}\end{array}$ \\
\hline $\begin{array}{c}\text { C. jwarancusa } \\
150 \mathrm{mg} / \mathrm{kg}\end{array}$ & $0.62 \pm 0.14$ & $1.40 \pm 0.20$ & $2.33 \pm 0.16$ & $2.95 \pm 0.26$ & $3.40 \pm 0.26$ & $6.41 \pm 0.46$ & $\begin{array}{c}11.73 \pm \\
0.84\end{array}$ & $16.08 \pm 1.33$ & $21.08 \pm 0.88$ & $27.23 \pm 0.94$ \\
\hline $\begin{array}{c}\text { C. jwarancusa } \\
300 \mathrm{mg} / \mathrm{kg}\end{array}$ & $0.95 \pm 0.15$ & $1.88 \pm 0.35$ & $2.85 \pm 0.47$ & $3.6 \pm 0.51$ & $4.23 \pm 0.49$ & $8.75 \pm 0.77$ & $\begin{array}{c}14.55 \pm \\
1.57\end{array}$ & $\begin{array}{c}20.75 \pm \\
2.08^{\star}\end{array}$ & $\begin{array}{c}26.66 \pm \\
1.72^{\star}\end{array}$ & $30.33 \pm 1.94$ \\
\hline $\begin{array}{c}\text { C. jwarancusa } \\
500 \mathrm{mg} / \mathrm{kg}\end{array}$ & $1.36 \pm 0.2^{*}$ & $2.71 \pm 0.37^{\star}$ & $3.66 \pm 0.20^{*}$ & $\begin{array}{c}5.13 \pm \\
0.75^{\star}\end{array}$ & $5.75 \pm 0.72^{\star}$ & $\begin{array}{c}9.51 \pm \\
1.31^{\star}\end{array}$ & $\begin{array}{c}17.91 \pm \\
1.99^{\star}\end{array}$ & $\begin{array}{c}26.16 \pm \\
2.95^{\star}\end{array}$ & $\begin{array}{l}30.25 \pm \\
3.09^{*}\end{array}$ & $34.0 \pm 3.14^{\star}$ \\
\hline
\end{tabular}

$\mathrm{n}=6$; Values are mean \pm S.E.M; Significant diuretic if $\mathrm{p}<{ }^{\star} 0.05$; Highly significant diuretic if $\mathrm{p}<{ }^{\star *} 0.001$. 
Table 2. Effect of $C$. jwarancusa on diuretic index and Lipschitz value.

\begin{tabular}{|c|c|c|c|c|c|}
\hline \multirow{2}{*}{ Groups } & \multirow{2}{*}{ Dose $\mathrm{mg} / \mathrm{kg}$} & \multicolumn{2}{|c|}{ Diuretic Index } & \multicolumn{2}{|c|}{ Lipschitz Value } \\
\hline & & Single Dose & Multiple Dose & Single Dose & Multiple Dose \\
\hline $10 \%$ DMSO & - & - & - & - & - \\
\hline Furosemide & 20 & 2.42 & 1.68 & - & - \\
\hline C. jwarancusa 1 & 150 & 1 & 1.22 & 0.41 & 0.72 \\
\hline C. jwarancusa 2 & 300 & 1.36 & 1.35 & 0.56 & 0.80 \\
\hline C. jwarancusa 3 & 500 & 1.48 & 1.52 & 0.61 & 0.90 \\
\hline
\end{tabular}

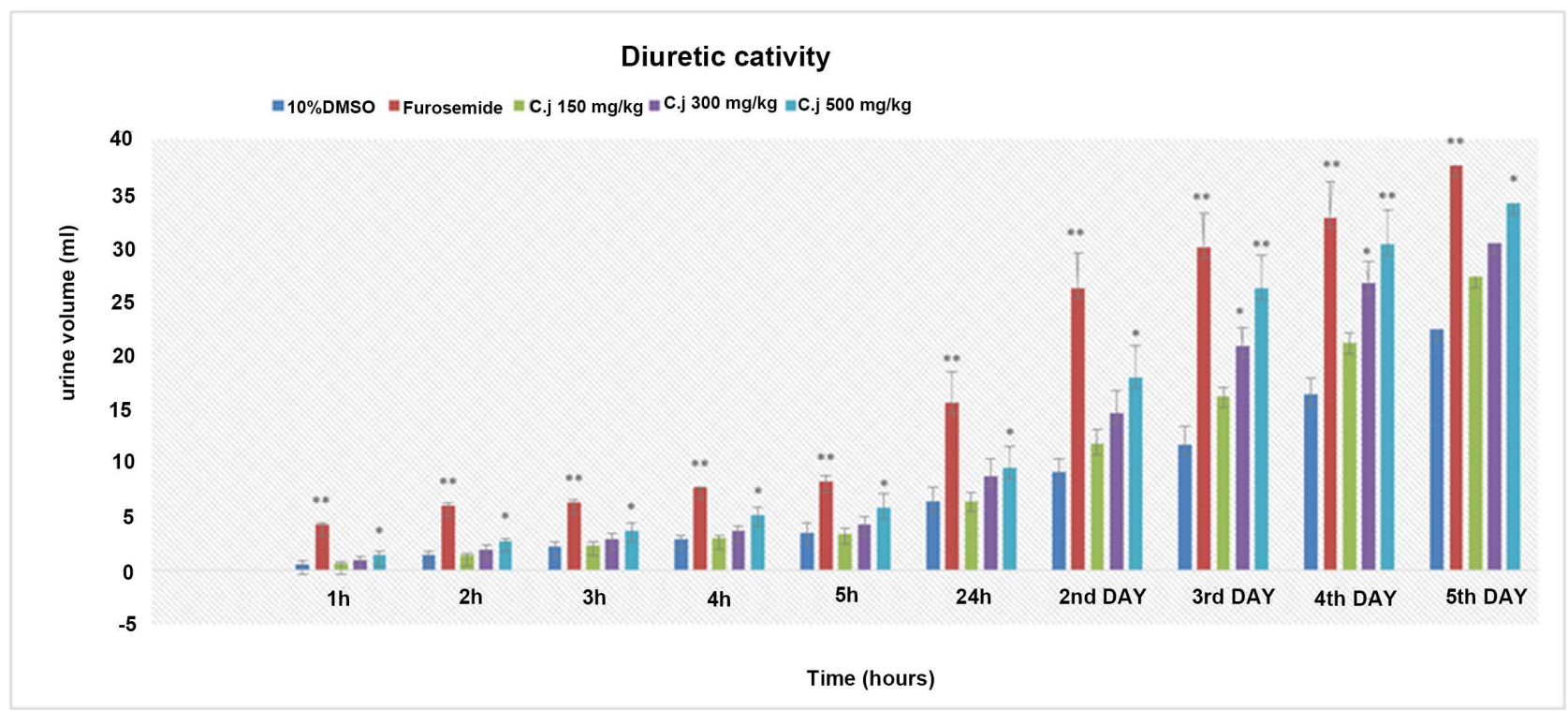

Figure 1. Comparison of urinary output after single and multiple-doses of various drugs. $\mathrm{n}=6$; Values are mean \pm S.E.M; Significant diuretic if ${ }^{\star} \mathrm{p}<0.05$ as compared to control; Highly significant diuretic if ${ }^{* *} \mathrm{p}<0.001$ as compared to control; CJ $=C y m b o-$ pogon jwarancusa.

almost one million people are dependent on herbal medicines for primary treatment of ailments and 21,000 herbal plants from all over the world have listed for possessing the medicinal properties [14]. In Unani Medicinal system the ethno pharmacological studies on $C$. jwarancusa illustrate its use as diuretic, but literature review reveals that no study have been performed to evaluate its diuretic action.

In this study different strengths of ethanol extract of $C$. jwarancusa were used to investigate diuretic activity, while furosemide was used as reference drug to compare the response of test drug. C. jwarancusa at $500 \mathrm{mg} / \mathrm{kg}$ showed significant diuretic effect after single and multiple doses, while $300 \mathrm{mg} / \mathrm{kg}$ extract displayed significant diuretic response only on 3rd and 4th day as compared to control, on basis of these findings it may be concluded that $C$. jwarancusa extract has dose-dependent diuretic response.

Terpenoids present in $C$. jwarancusa have been reported to have diuretic activity. Terpenoids prevent the actions of aldosterone by binding to A1 receptor, 
thus causing diuresis [15]. Terpenoids constitute approximately $65 \%-70 \%$ of the total composition in $C$. jwarancusa. Hence the diuretic activity of $C$. jwarancusa may be due to high composition of terpenoids. In future, studies could be carried out to isolate active pharmacological constituents and determine their actual mechanism of action.

Previously other species of Cymbopogon were also reported to have a diuretic response. $C$. citratus leaf decoction showed mild diuretic effects in rats at $10 \%$ and $20 \%$ [16]. C. schoenanthus extract also showed significant urine output values in combination with glycolic acid [17].

Patel [18] has categorized diuretics as good, moderate and poor on the basis of diuretic index, hence it may be concluded that according to diuretic index $C$. jwarancusa falls in the category of moderate diuretic at all doses and may be used safely.

\section{Acknowledgements}

Authors are thankful to Department of Pharmacology, University of Karachi for providing facilities to complete this piece of work.

\section{References}

[1] Hymes, L. and Warshaw, B. (1987) Thiazide Diuretics for the Treatment of Children with Idiopathic Hypercalciuria and Hematuria. The Journal of Urology, 138, 1217-1219. https://doi.org/10.1016/S0022-5347(17)43554-3

[2] Salvetti, A. and Ghiadoni, L. (2006) Thiazide Diuretics in the Treatment of Hypertension: An Update. Journal of the American Society of Nephrology, 17, S25-S29. https://doi.org/10.1681/ASN.2005121329

[3] Kearney, P.M., Whelton, M., Reynolds, K., Muntner, P., Whelton, P.K. and He, J. (2005) Global Burden of Hypertension: Analysis of Worldwide Data. The lancet, 365, 217-223. https://doi.org/10.1016/S0140-6736(05)70151-3

[4] Puschett, J.B. (1994) Pharmacological Classification and Renal Actions of Diuretics. Cardiology, 84, 4-13. https://doi.org/10.1159/000176450

[5] Sica, D.A. (2004) Diuretic-Related Side Effects: Development and Treatment. The Journal of Clinical Hypertension, 6, 532-540. https://doi.org/10.1111/j.1524-6175.2004.03789.x

[6] Kirtikar, K. and Basu, B. (1982) Indian Medicinal Plants. 2nd Edition, Vol. I \& II, Dehradun.

[7] Jones, W., Hastings, W. and Chambers, W. (1796) Dissertations and Miscellaneous Pieces Relating to the History and Antiquities, the Arts, Sciences, and Literature, Of Asia. Being a Continuation of Extracts from the Asiatic Researches, Vol. 2, London.

[8] Alam, M.K., Ahmed, S., Anjum, S., Akram, M., Shah, S.M.A., Wariss, H.M., Hasan, M.M. and Usmanghani, K. (2016) Evaluation of Antipyretic Activity of Some Medicinal Plants from Cholistan Desert Pakistan. Pakistan Journal of Pharmaceutical Sciences, 29, 529-533.

[9] Bhuyan, P.D., Chutia, M., Pathak, M. and Baruah, P. (2010) Effect of Essential Oils from Lippia geminata and Cymbopogon jwarancusa on in Vitro Growth and Sporulation of Two Rice Pathogens. Journal of the American Oil Chemists' Society, 87, 1333-1340. https://doi.org/10.1007/s11746-010-1620-z 
[10] Bose, S., Ammani, K. and Ratakumari, S. (2013) Chemical Composition and Its Antibacterial Activity of Essential Oil from Cymbopogon jwarancusa. International Journal of Biopharma Research, 2, 97-100.

[11] Dar, M.Y., Shah, W.A., Rather, M.A., Qurishi, Y., Hamid, A. and QurishI, M. (2011) Chemical Composition, in Vitro Cytotoxic and Antioxidant Activities of the Essential Oil and Major Constituents of Cymbopogon jawarancusa (Kashmir). Food Chemistry, 129, 1606-1611. https://doi.org/10.1016/j.foodchem.2011.06.016

[12] (1996) Council NR: Guide for the Care and Use of Laboratory Animals. 8th Edition, National Academy Press, Washington DC.

[13] Asif, M., Atif, M., Malik A.S.A., Dan, Z.C., Ahmad, I. and Ahmad, A. (2013) Diuretic Activity of Trianthema portulacastrum Crude Extract in Albino Rats. Tropical Journal of Pharmaceutical Research, 12, 967-997.

https://doi.org/10.4314/tjpr.v12i6.15

[14] Singh, A., Singh, K. and Saxena, A. (2010) Hypoglycemic Activity of Different Extracts of Various Herbal Plants. International Journal of Research in Ayurveda and Pharmacy, 1, 212-224.

[15] Rizvi, S.H., Shoeb, A., Kapil, R.S. and Popli, S.P. (1980) Two Diuretic Triterpenoids from Antidesma menasu. Phytochemistry, 19, 2409-2410. https://doi.org/10.1016/S0031-9422(00)91037-9

[16] Carbajal, D., Casaco, A., Arruzazabala, L., Gonzalez, R. and Tolon, Z. (1989) Pharmacological Study of Cymbopogon citratus Leaves. Journal of Ethnopharmacology, 25, 103-107. https://doi.org/10.1016/0378-8741(89)90049-4

[17] Al-Ghamdi, S.S., Al-Ghamdi, A.A. and Shammah, A.A. (2007) Inhibition of Calcium Oxalate Nephrotoxicity with Cymbopogon schoenanthus (Al-Ethkher) Drug Metabolism Letters, 1, 241-244. https://doi.org/10.2174/187231207783221420

[18] Patel, U., Kulkarni, M., Undale, V. and Boshale, A. (2009) Evaluation of Diuretic Activity of Aqueous and Methanol Extracts of Lepidium sativum Garden Cress (Cruciferae) in Rats. Tropical Journal of Pharmaceutical Research, 8, 215-219. https://doi.org/10.4314/tjpr.v8i3.44536 